\title{
Renewable energy: a bibliometric analysis
}

\author{
Anna Rosokhata ${ }^{1}{ }^{*}$, Mariia Minchenko ${ }^{1}$, Liliya Khomenko $^{1}$, Olena Chygryn ${ }^{1}$ \\ ${ }^{1}$ Department of Marketing, Academic and Scientific Institute of Business, Economics and \\ Management, Sumy State University, 2, Rymskogo-Korsakova st., 40007 Sumy, Ukraine
}

\begin{abstract}
The aims of this paper are to identify existing research on renewable energy; identify the most influential publications, authors, organizations to understand the research areas. The paper is centered on the bibliometric analysis based on the Web of Science database for the key phrase' renewable energy' in the article title until 2020. We analyzed the publications about renewable energy by years, by research areas, by geography, by research organizations and research sponsors, by journals, by citations of journals, authors, publications, co-occurrence by keywords. Analysis of the most cited publications and authors, analysis of cooccurrence by keywords was performed using VOSviewer. We performed hierarchical cluster analysis, and clusters were selected using VOSviewer. We found 17805 scientific publications on renewable energy published in scientific journals $(51.7 \%$ of publications were published during 2016-2020). The most popular research areas are energy fuels, engineering, science technology, environmental sciences, ecology, and business economics. The majority of papers was published by the scientists from the United States, China, and India. In addition, we identified six main research clusters. They are related to an optimizer, renewable energy, biomass, co 2 emissions, model, desalination. Conclusions: This analysis confirmed the author's hypothesis about the definition of new scientific horizons of renewable energy research. Our results can help scientists interested in renewable energy looking for research funding and research project risks based on renewable energy.
\end{abstract}

\section{Introduction}

All over the world, the study of renewable energy draws interest of various scientific schools, economics, and especially stakeholders, who can benefit from the use of renewable energy technologies [1-7]. Resource constraints, sustainable energy, biomass, co 2 emissions make it possible to establish the hypothesis of the transfer of scientific interests from energy fuels and environmental sciences ecology to other areas. The definition of the role and place of renewable energy in business economics, mechanical engineering, science technology and compute science is gaining more and more popularity [8-17].

In addition, the essential study of modern scientific schools on renewable energy has a number of patterns, confirming that it is possible to obtain sound theses to determine the

\footnotetext{
* Corresponding author: a.rosokhata@kmm.sumdu.edu.ua
} 
features of optimization of financial, intellectual and labor resources in the development of renewable energy research in modern space [18-23].

Modern energy systems are undergoing a revolutionary change. Significant influence on these changes is lobbied by various organizations of world importance and economically developed countries [24-26]. We are currently observing:

- adjusting the operation of more flexible architectures of energy systems;

- development of intelligent networks and their interaction with energy storage and use technologies;

- scaling the market of active consumers, for whom the origin of energy is important;

- reorganization of the electricity market and development of cloud technology technologies, energy net.

But not in all countries you can see support for the development of renewable energy. Although these areas of research and implementation at the industrial level can be actively promoted in the digital environment [27-29]. In this paper, we aim to examine the place of renewable energy in various areas of research [30-34], as well as to identify the relationship between renewable energy and economic aspects. The main objectives of this study are to substantiate the following assumptions:

1. Renewable energy research vectors are moving towards business economics. The economic benefits of implementation and the financial risks that businesses may incur during the implementation of renewable energy projects are becoming an increasingly important issue.

2. The issue of renewable energy is interesting to absolutely all countries and the geographical location of scientific schools should be ignored. It is more appropriate to emphasize the study of research sponsorship, ie those stakeholders who may later become the owners of these studies results.

3. There is a subjective statement that renewable energy is more related to $\mathrm{CO} 2$ emissions and their system of optimizing storage and using. Modern researchers are already paying more attention to such issues as desalination, hydrogen energy, power electronics, biomass.

Therefore, our research focuses on the peculiarities of the development of research in the field of renewable energy, and determining the patterns of this issue.

The main direction of this paper is bibliometric analysis of the scientific literature on renewable energy. It allows to form a holistic view of existing research on selected topics, to identify the most influential publications, authors and organizations, to analyze the directions of existing and future research.

The aim of the work is to analyze existing research of renewable energy, to identify the most influential publications, authors, organizations patterns of development research areas.

This study analyzes the impact of journals, authors and articles, analyzes research areas, research geography, renewable energy organizations and sponsors such studies. In the end of the article the analysis of co-occurance by keywords and recommendations for possible further research is proposed.

\section{Materials and methods}

At the beginning of the analysis, the methods used for bibliometric analysis [35-38] were analyzed. As a result, the analysis application of the most cited publications and authors, analysis of co-occurrence by keywords using the program VOSviewer was selected. To do this, we first selected all scientific publications on renewable energy based on the Web of Science database for the keyword phrase "renewable energy" in the article title until 2020 inclusive. 17805 scientific publications were found.

Based on 17,805 publications found in the Web of Science database, a sample of 2,000 publications was formed. All publications were sorted by the number of citations from the 
largest to the smallest, the first 2000 publications were included in the sample as the most relevant (probability 95\%, confidence interval $2.06 \%$ ).

It was analysed of several sets of publications on renewable energy by years (1974-2020), by research areas, by geography, by organizations that conduct research and sponsor research, by publications, by citations of publications, authors, publications, co-occurrence by keywords. For each indicators it were identified the ten most popular fields of research, countries, organizations, publications, authors, publications, which were displayed using graphical and tabular methods.

It was performed the hierarchical cluster analysis and it were selected clusters using VOSviewer based on keywords. Keywords with more than 45 repetitions excluding geographical names were selected, a sample of 2000 publications from the Web of Science database (95\% probability, $2.06 \%$ confidence interval).

\section{Results and discussions}

Carrying out bibliometric analysis and searching for scientific publications on issues related to the energy system is the key to the formation of a system removing communication and organizational barriers to stakeholders' interaction. In order to properly construct these approaches, 17805 scientific publications (articles, reviews, book sections, abstracts, etc.) published during 1974-2020 were found in the Web of Science database, primarily for the analysis of renewable energy publications. The number of publications by year is presented in Fig. 1.

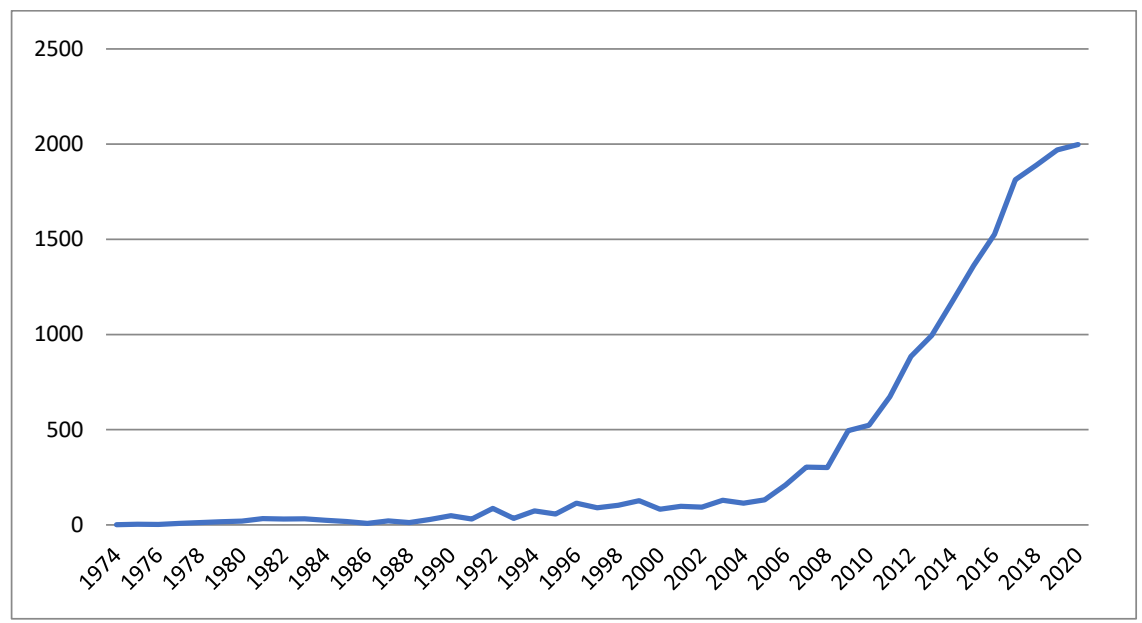

Fig. 1. Number of publications on renewable energy by years based on the Web of Science database (created by the authors)

As can be seen from Fig. 1, 51.7\% of publications were published during 2016-2020, which indicates a relatively recent increase in research in this area.

Research on renewable energy is being studied by scientists in various fields of application. The ten most popular areas of research are presented in Fig. 2. 


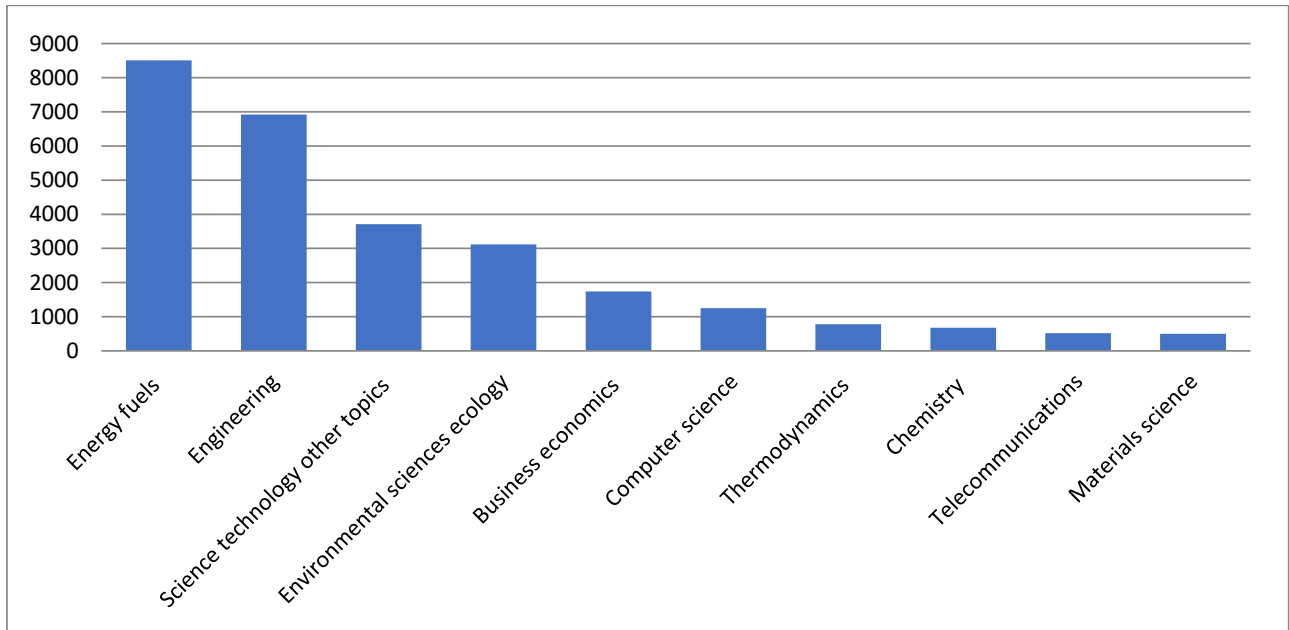

Fig. 2. The most popular areas of research based on the Web of Science database (created by the authors)

As can be seen from Fig. 2, most research concerns Energy fuels (47.8\%), Engineering (38.9\%), Science technology other topics (20.9\%), Environmental sciences ecology $(17.5 \%)$ and Business economics $(9.8 \%)$.

Researchers from around the world deal with renewable energy issues. In fig. 3 presents the countries whose scientists have written the most scientific works.

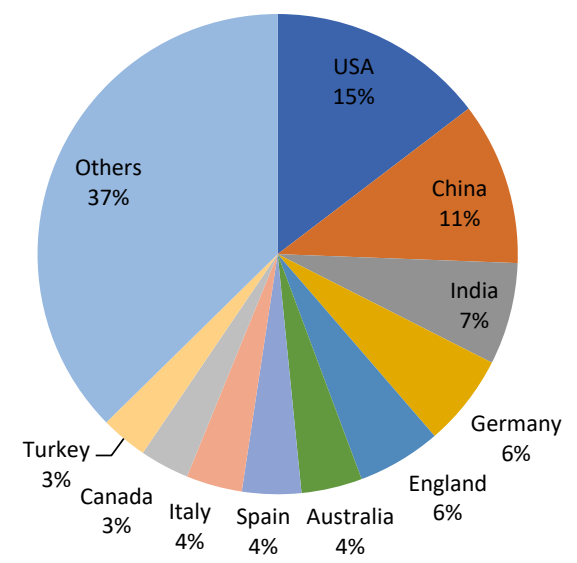

Fig. 3. Number of publications on renewable energy by country based on the Web of Science database (generated by the authors)

As can be seen from Fig. 3, most papers have been published by researchers from the United States (2606 papers), China (1951 papers) and India (1223 papers). At the same time, in some regions, including Ukraine, this topic is insufficiently studied (59 works).

More than 500 organizations conduct research on selected topics. The ten organizations that conduct the most research on selected topics are presented in Fig.4. 


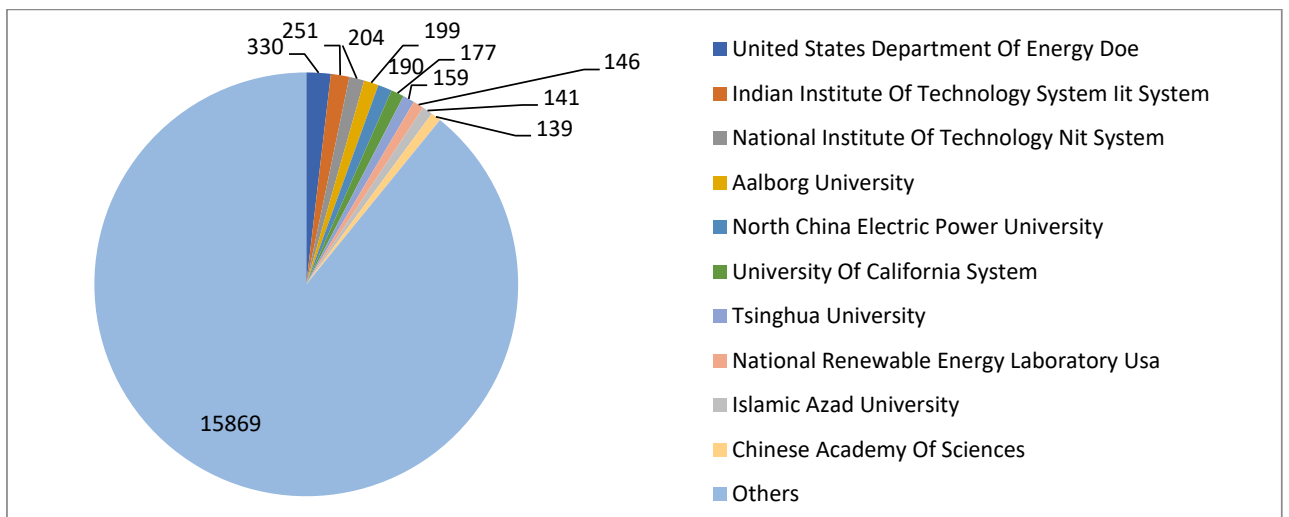

Fig. 4. The organizations that conduct the most research on the basis of the Web of Science database (formed by the authors)

Acording Fig. 4, the most renewable energy issues are dealt with by the United States Department of Energy Doe (1.9\%), Indian Institute of Technology System Iit System (1.4\%), National Institute of Technology Nit System (1.1\%), Aalborg University (1.1\%), North China Electric Power University (1.0\%).

The research is sponsored by more than 500 organizations. In fig. 5 presents the ten organizations that most often invest in the development of research of renewable energy.

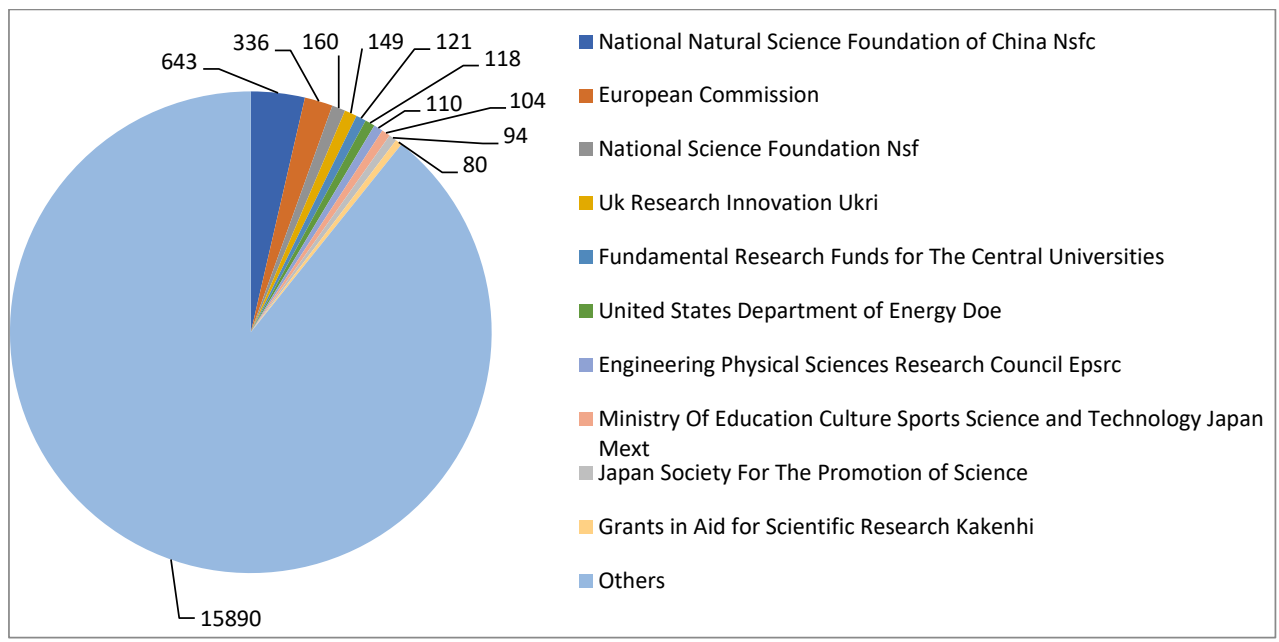

Fig. 5. Organizations that sponsor renewable energy research based on the Web of Science database (created by the authors)

The most frequent sponsors of the research are the National Natural Science Foundation of China Nsfc (3.6\%), the European Commission (2.1\%), the National Science Foundation Nsf $(0.9 \%)$ and Uk Research Innovation Ukri (0.8\%). (Figure 5).

Renewable energy publications were published in more than 100 publications, with almost a quarter of all publications were published in ten journals (Figure 6). 


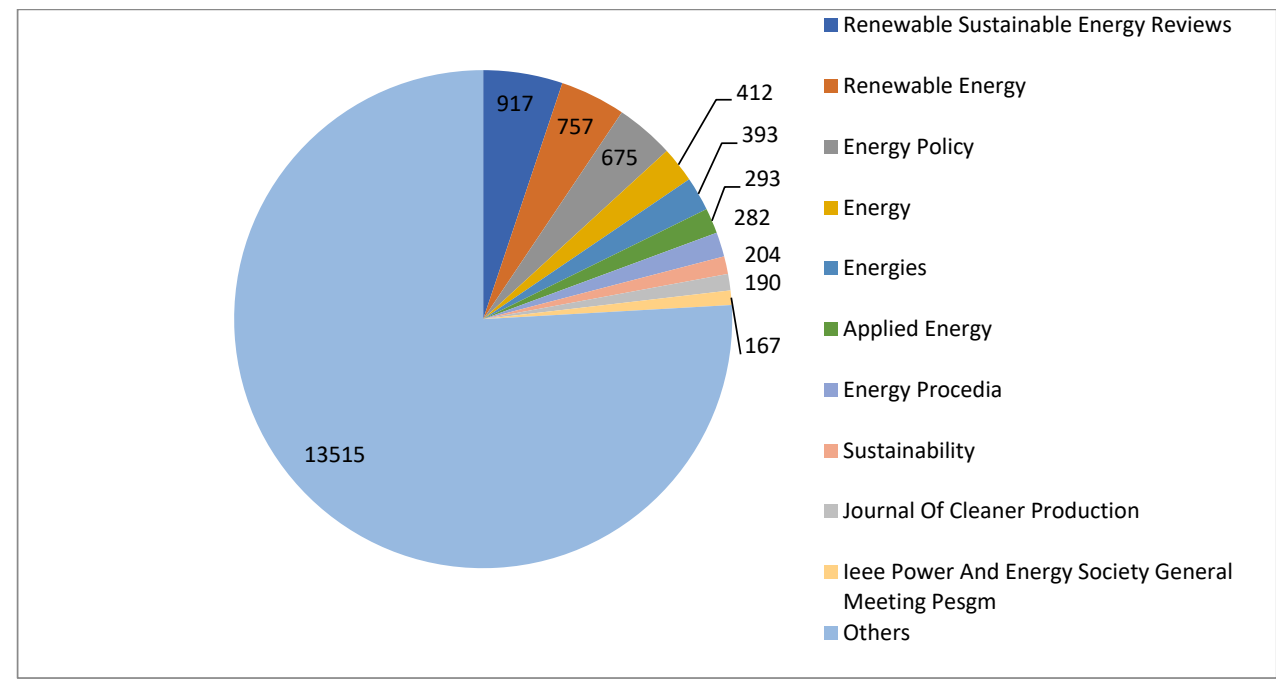

Fig. 6. Journals with the largest number of publications by country based on the Web of Science database (created by the authors)

The most popular magazines are "Renewable Sustainable Energy Reviews" (5.2\%), "Renewable Energy" (4.3\%), "Energy Policy" (3.8\%), "Energy" (2.3\%), "Energies". (2.2\%). It can indicate the influence of these publications on selected topics.

To determine the influence of journals, we analyzed citations. The most cited publications with at least five publications are presented in Table 1.

Table 1. The most cited publications on renewable energy based on a sample from the Web of Science database (created by the authors)

\begin{tabular}{|l|c|c|}
\hline \multicolumn{1}{|c|}{ Journals } & $\begin{array}{c}\text { Number of } \\
\text { citations }\end{array}$ & $\begin{array}{c}\text { Number of } \\
\text { publications }\end{array}$ \\
\hline Renewable Sustainable Energy Reviews & 43720 & 443 \\
\hline Energy Policy & 22471 & 227 \\
\hline Renewable Energy & 13317 & 180 \\
\hline Energy & 9041 & 116 \\
\hline Applied Energy & 8602 & 100 \\
\hline Ieee Transaction on Industrial Electronic & 4412 & 20 \\
\hline Energy Economics & 4119 & 41 \\
\hline Energy Conversion and Management & 3503 & 47 \\
\hline International Journal of Hydrogen Energy & 2720 & 26 \\
\hline Ieee Transaction on Power System & 2401 & 19 \\
\hline
\end{tabular}

Thus, both lists includes only five publications: Renewable Sustainable Energy Reviews, Energy Policy, Renewable Energy, Energy and Applied Energy. It indicates their impact on the subject.

In order to determine the most influential scientists in the chosen field, we identified the most cited authors. The most cited authors with at least five publications are presented in Table 2 . 
Table 2. The most cited authors on renewable energy based on a sample from the Web of Science database (generated by the authors)

\begin{tabular}{|l|c|c|}
\hline \multicolumn{1}{|c|}{ Authors } & Number of citations & Number of publications \\
\hline Lund H. & 5898 & 23 \\
\hline Mathiesoen B.V. & 2825 & 8 \\
\hline Connolly D. & 1992 & 6 \\
\hline Apergis N. & 1808 & 7 \\
\hline Payne J.E. & 1755 & 7 \\
\hline Ozturk I. & 1434 & 7 \\
\hline Walker G. & 1310 & 8 \\
\hline Devine-Wright P. & 1300 & 12 \\
\hline Saini R.P. & 1295 & 6 \\
\hline Blaabjerg F. & 1145 & \\
\hline
\end{tabular}

Each authors has at least six publications, and Lund H. 23 publications that provided the largest number of citations (Table 2). It is indicated the influence of the authors' data on the topic of renewable energy.

Table 3. The most cited articles on renewable energy based on the Web of Science database (created by the authors)

\begin{tabular}{|c|c|c|c|c|}
\hline Authors & Title article & Journal & $\begin{array}{c}\text { Year of } \\
\text { publication }\end{array}$ & $\begin{array}{c}\text { Number of } \\
\text { citations }\end{array}$ \\
\hline $\begin{array}{l}\text { Carrasco J.M. } \\
\text { et al. [39] }\end{array}$ & $\begin{array}{l}\text { Power-electronic systems for the } \\
\text { grid integration of renewable } \\
\text { energy sources: A survey }\end{array}$ & $\begin{array}{l}\text { Ieee } \\
\text { Transactions on } \\
\text { Industrial } \\
\text { Electronics }\end{array}$ & 2006 & 2237 \\
\hline $\begin{array}{l}\text { Panwar N. L. } \\
\text { et al. [40] }\end{array}$ & $\begin{array}{l}\text { Role of renewable energy sources } \\
\text { in environmental protection: A } \\
\text { review }\end{array}$ & $\begin{array}{l}\text { Renewable \& } \\
\text { Sustainable } \\
\text { Energy } \\
\text { Reviews }\end{array}$ & 2011 & 1233 \\
\hline $\begin{array}{l}\text { Kempton W \& } \\
\text { Tomic J. [41] }\end{array}$ & $\begin{array}{l}\text { Vehicle-to-grid power } \\
\text { implementation: From stabilizing } \\
\text { the grid to supporting large- } \\
\text { scale renewable energy }\end{array}$ & $\begin{array}{l}\text { Journal of } \\
\text { Power Sources }\end{array}$ & 2005 & 1092 \\
\hline $\begin{array}{l}\text { Wuestenhagen } \\
\text { R., Wolsink M. } \\
\text { \& Buerer M.J. } \\
{[42]}\end{array}$ & $\begin{array}{l}\text { Social acceptance of renewable } \\
\text { energy innovation: An introduction } \\
\text { to the concept }\end{array}$ & Energy Policy & 2007 & 1082 \\
\hline $\begin{array}{l}\text { Turner J.A. } \\
{[43]}\end{array}$ & $\begin{array}{l}\text { A realizable renewable energy } \\
\text { future }\end{array}$ & Science & 1999 & 1012 \\
\hline Dincer I. [44] & $\begin{array}{l}\text { Renewable energy and sustainable } \\
\text { development: a crucial review }\end{array}$ & $\begin{array}{l}\text { Renewable \& } \\
\text { Sustainable } \\
\text { Energy } \\
\text { Reviews } \\
\end{array}$ & 2000 & 902 \\
\hline $\begin{array}{l}\text { Banos R. et al. } \\
{[45]}\end{array}$ & $\begin{array}{l}\text { Optimization methods applied } \\
\text { to renewable and sustainable } \\
\text { energy: A review }\end{array}$ & $\begin{array}{l}\text { Renewable \& } \\
\text { Sustainable } \\
\text { Energy } \\
\text { Reviews }\end{array}$ & 2011 & 869 \\
\hline $\begin{array}{l}\text { Connolly D. et } \\
\text { al. [46] }\end{array}$ & $\begin{array}{l}\text { A review of computer tools for } \\
\text { analysing the integration of } \\
\text { renewable energy into various } \\
\text { energy systems }\end{array}$ & Applied Energy & 2010 & 857 \\
\hline
\end{tabular}




\begin{tabular}{|l|l|l|c|c|}
\hline $\begin{array}{l}\text { Ellabban O., } \\
\text { Abu-Rub H. \& } \\
\text { Blaabjerg F. } \\
{[47]}\end{array}$ & $\begin{array}{l}\text { Renewable energy resources: } \\
\text { Current status, future prospects and } \\
\text { their enabling technology }\end{array}$ & $\begin{array}{l}\text { Renewable \& } \\
\text { Sustainable } \\
\text { Energy } \\
\text { Reviews }\end{array}$ & 2014 & 818 \\
\hline $\begin{array}{l}\text { Barton J.P. \& } \\
\begin{array}{l}\text { Infield D.G. } \\
{[48]}\end{array}\end{array}$ & $\begin{array}{l}\text { Energy storage and its use with } \\
\text { intermittent renewable energy }\end{array}$ & $\begin{array}{l}\text { Ieee } \\
\text { Transactions on } \\
\text { Energy } \\
\text { Conversion }\end{array}$ & 2014 & 743 \\
\hline
\end{tabular}

Table 3 shows that all articles were published before 2014, with the oldest article published in 1999.

To understand the areas of research, a co-occurrence analysis was performed by keywords. Figure 7 presents the results of hierarchical cluster analysis with the number of repetitions from 45 except for geographical names in the sample. The sample includes the 2000 most cited publications based on the Web of Science database (95\% probability, $2.06 \%$ confidence interval).

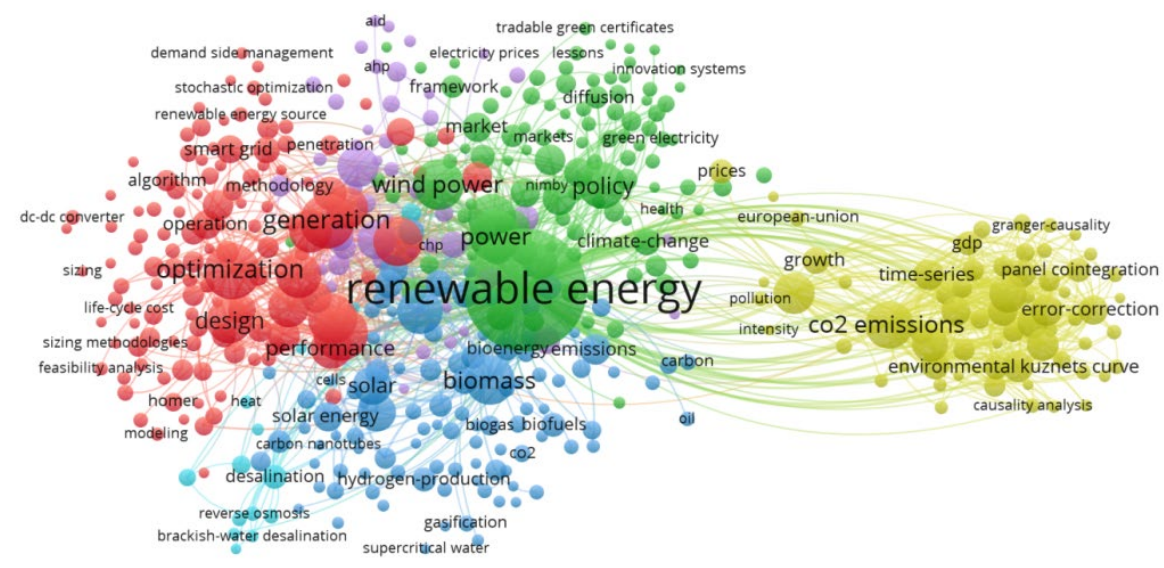

vosviewer

Fig 7. Analysis of co-occurrence by keywords (Web of Science database, sample of 2000 publications, more than 45 keyword duplications excluding geographical names).

Fig. 7 shows that there are six main clusters: 116)

Cluster 1 (123 items): optimizator (Links: 213, Total links straight: 689, occurrences:

Cluster 2 (106 items): renewable energy (Links: 414, Total links straight: 2656, occurrences: 549$)$

Cluster 3 (102 items): biomas (Links: 200, Total links straight: 529, occurrences: 93)

Cluster 4 (65 items): co2 emissions (Links: 145, Total links straight: 733, occurrences: 86)

Cluster 5 (47 items): model (Links: 167, Total links straight: 353, occurrences: 63)

Cluster 6 (15 items): desalinetion (Links: 70, Total links straight: 145, occurrences: 22). 


\section{Conclusions}

In general, this paper considers the historical development of renewable energy research in different areas: temporal, geographical, authorial, sponsorship of scientific fields, implementation of scientific journals. This approach has identified a few patterns that can justify further research.

The chosen time lag of 45 years showed the relevance of this topic in the last 10 years and allowed to divide the time period into 2 stages. There was a constant interest in the topic (up to 200 publications per year) until 2006. There was intense revitalization of scientists to renewable energy in 2006-2020. Based on this, we can conclude about the relevance of this topic and the fact that in the future it is necessary to more meaningfully study the period 2006-2020 with detailing and make the additional divisions into stages in this time period.

In this work, we were able to confirm the study vector of renewable energy. Indeed, almost $2 / 3$ of all work belongs to energy fuels and engineering. But in the research of this issue, concentrated in the active period of 2006-2020, we saw a trend of increasing research renewable energy in business economics, mechanical engineering, science technology and computer science.

An interesting result of the study concerns the researchers affiliation to the country. We have suggested that the topic of renewable energy is most interesting for economically developed countries that can afford to invest in this area. But the analysis revealed that most of the work has been published by researchers from the United States, China and India. None of the G7 countries, except the United States, is actively involved in the scientific development of renewable energy. It turns out that our assumption about the non-neglect of geographical localization must also be taken into account. Therefore, it is necessary to pay attention to the work of the following research centers: United States Department of Energy Doe, Indian Institute of Technology System Iit System, National Institute of Technology Nit System, Aalborg University, North China Electric Power University.

But the issues of research sponsorship has shown the role of the European Union and the United Kingdom in the study of renewable energy, where they influence research through the European Commission and Uk Research Innovation Ukri.

A rather pleasant fact is that the world community is interested in renewable energy issues and actively presents its own results in those journals that are authoritative. And in these 5 magazines more than $80 \%$ of all publications of explored authors are published. Authors citation indexes indicate their publications relevance and the renewable energy influencing in general.

Conducting co-occurrence research on keywords allowed us to identify six main clusters related to optimization, renewable energy, biomass, $\mathrm{CO} 2$ emissions, model, desalination. This analysis confirmed the author's assumptions about the definition of new scientific horizons of renewable energy research.

The results can be of value to those scientists who are interested in the topic of renewable energy, especially the prospects for the development of the financial investment rationale, risk research of projects based on renewable energy.

\section{References}

1. A. El Amri, R. Boutti, S. Oulfarsi, F. Rodhain, B. Bouzahir. Financial Markets, Institutions and Risks, 4(4), 31-44 (2020)

2. A. El Amri, R. Boutti, F. Rodhain. Financial Markets, Institutions and Risks, 4(2), 52$64(2020)$

3. M. Smith. A SocioEconomic Challenges, 2(1), 21-34 (2018)

4. D. Bhowmik. SocioEconomic Challenges, 3(2), 15-30 (2019) 
5. O. Lyulyov, T., Pimonenko, A. Kwilinski, H. Dzwigol, M. Dzwigol-Barosz, V. Pavlyk,

P. Barosz. Energies, 14(2), 373 (2021)

6. D.T.A. Marcel. SocioEconomic Challenges, 3(2), 63-69 (2019)

7. I. Didenko, K. Volik, T. Vasylieva, S. Lyeonov, N. Antoniuk. E3S Web of Conferences, $202(2020)$

8. Y. Samusevych, A. Vysochyna, T. Vasylieva, S. Lyeonov, S. Pokhylko, E3S Web of Conferences, 234 (2021)

9. S. Furmaniak, P.A. Gauden, A. Patrykiejew, R. Miśkiewicz, P. Kowalczyk, Scientific Reports, 15407 (2018)

10. He, Shuquan. Business Ethics and Leadership, 3(4), 43-48 (2019)

11. V. Pavlyk, SocioEconomic Challenges, 4(1), 122-128 (2020)

12. V. Panchenko, Yu. Harust, Ya. Us, O. Korobets, V. Pavlyk, Marketing and Management of Innovations, 1, 256-264 (2020)

13. Ya. Us, T. Pimonenko, T. Tambovceva, J-P Segers, Health Economics and Management Review, 1(1), 48-59 (2020)

14. R. Miskiewicz, Energies, 13(22), 6106 (2020)

15. R. Miskiewicz, Polityka Energetyczna, 21(2), 49-62 (2018)

16. Y. Kharazishvili, A. Kwilinski, O. Grishnova, H. Dzwigol, Sustainability, 12(21), 8953 (2020)

17. H.Dzwigoł, M. Dzwigoł-Barosz, Z. Zhyvko, R. Miskiewicz, H. Pushak, Journal of Security and Sustainability Issues, 8(3), 307-317 (2019)

18. O. Y. Halan, Marketing and Management of Innovations, 1, 196-206 (2018)

19. I. Sotnyk, I. Shvets, L. Momotiuk, Y. Chortok, Marketing and Management of Innovations, 4, 150-160 (2018)

20. R. Vanickova, Marketing and Management of Innovations, 2, 56-67 (2020)

21. H.Dkhili, L. B. Dhiab, Marketing and Management of Innovations, 4, 252-268 (2019)

22. V. Pavlyk, Financial Markets, Institutions and Risks, 4(1), 117-123 (2020)

23. L. Starchenko, S. Lyeonov, T. Vasylieva, T. Pimonenko, O. Lyulyov, E3S Web of Conferences, 234, 00015 (2021)

24. O. Chygryn, A. Rosokhata, O. Rybina, N. Stoyanets, E3S Web of Conferences, 234, 00004 (2021)

25. I. Vakulenko, L. Saher, L. Syhyda, S. Kolosok, A. Yevdokymova, E3S Web of Conferences, 234, 00020 (2021)

26. Ye. Ziabina, T. Pimonenko, L. Starchenko, L. SocioEconomic Challenges, 4(4), 160$174(2020)$

27. H. S. Andrade, G. Loureiro, Business Ethics and Leadership, 4(2), 86-95

28. A. Rosokhata, O. Rybina, A. Derykolenko, V. Makerska, Research in World Economy, 11(4), 42-52 (2020)

29. H. Dzwigol, M. Dzwigol-Barosz, Academy of Strategic Management Journal, 19(5), 17, (2020)

30. Y. Bilan, T. Vasylieva, S. Lyeonov, I. Tiutiunyk. Entrepreneurial Business and Economics Review, 7(2), 27-43 (2019)

31. O. Chygryn, O. Lyulyov, T. Pimonenko, S. Mlaabdal. Engineering Management in Production and Services, 12(4), 92-104 (2020)

32. O. Lyulyov, T. Pimonenko, N. Stoyanets, N. Letunovska. Research in World Economy, 10(4), 97-105 (2019)

33. M.P. Bhandari. Business Ethics and Leadership, 3(1), 101-108 (2019)

34. K. Djalilov, S. Lyeonov, A. Buriak, Risk Governance and Control: Financial Markets and Institutions, 5(4CONT1), 178-187 (2015)

35. L. Saher, L. Syhyda, O. Korobets, T. Berezianko, E3S Web of Conferences, 234, 00011 (2021) 
36. Y. Bilan, T. Pimonenko, L. Starchenko, E3S Web of Conferences, 159, 04037 (2020)

37. L. Khomenko, L. Saher, J. Polcyn, Health Economics and Management Review, 1(1), 20-36 (2020).

38. A. Zolkover, V.Terziev, Business Ethics and Leadership, 4(3), 107-118 (2020)

39. J. M. Carrasco, L.G Franquelo, J.T. Bialasiewicz, E. Galvan, R. Portillo, M.M. Prats, J.I. Leon, N. Moreno-Alfonso, IEEE Transactions on Industrial Electronics. 4(53), 1002-1016 (2006)

40. N. L. Panwar, S.C Kaushik, S. Kothari, Renewable \& Sustainable Energy Reviews. 3(15), 1513-1524 (2011)

41. W. Kempton, I. Tomic, Journal of Power Sources. 1(144), 280-294 (2005)

42. R. Wuestenhagen, M. Wolsink, M. J. Buerer. Energy Policy. 5(35), 2683-2691 (2007)

43. J.A. Turner, Science. 5428(285), 687-689 (1999)

44. I. Dincer I. Renewable \& Sustainable Energy Reviews. 2(4), 157-175 (2011)

45. R. Banos, F. Manzano-Agugliaro, F. Montoya, C. Gil, A. Alcayde, J. Gome, Renewable \& Sustainable Energy Reviews. 4(15), 1753-1766 (2011)

46. D. Connolly, Applied Energy, 4(87), 1059-1082 (2010)

47. O. Ellabban, H. Abu-Rub, Renewable \& Sustainable Energy Reviews. 39, 748-764 (2014)

48. J.P. Barton, IEEE Transactions on Energy Conversion, 2(19), 441-448 (2014) 